\title{
Translation and transcultural memory in La voz dormida
}

\section{Alicia Castillo Villanueva \& Lucía Pintado Gutiérrez}

To cite this article: Alicia Castillo Villanueva \& Lucía Pintado Gutiérrez (2021) Translation and transcultural memory in La voz dormida, Perspectives, 29:1, 156-170, DOI: 10.1080/0907676X.2019.1690010

To link to this article: https://doi.org/10.1080/0907676X.2019.1690010

$$
\text { 曲 Published online: } 26 \text { Nov } 2019 .
$$

Submit your article to this journal ๔

Џ Article views: 363

Q View related articles $\longleftarrow$

View Crossmark data $\nearrow$ 


\title{
Translation and transcultural memory in La voz dormida
}

\author{
Alicia Castillo Villanueva and Lucía Pintado Gutiérrez \\ School of Applied Language and Intercultural Studies, Dublin City University, Dublin, Ireland
}

\begin{abstract}
This article examines the role of translation in mediating memory and makes the case for translation and memory based on the transcultural framework by Erll and that of translation in mediating memory by Deane-Cox. This work specifically problematises the transmission of the experiences of trauma and violence against Republican women after the Spanish Civil War as represented in La Voz dormida by Dulce Chacón and its translation, The Sleeping Voice. We explore synergies among the aforementioned disciplines and the possibilities and challenges involved in translation in the realm of postmemory, claiming the importance of the ethical position of the writer as well as that of the translator as guardians of memory. Our exploration focuses on the Spanish Civil War and dictatorship and aims to contribute to the emerging scholarship in translation and memory studies.
\end{abstract}

\section{ARTICLE HISTORY}

Received 9 January 2019

Accepted 31 October 2019

\section{KEYWORDS}

Guardian; mediating memory; postmemory; transcultural memory; translation; trauma

\section{Translation and memory studies: an applied approach}

In recent times, interest in memory and its numerous manifestations has been on the rise across various fields, following the phenomenon of 'turn to memory'. In this article, we address the complexity of mediating memory based on Deane-Cox (2013), and the challenges of representing memory in literature and its translations. The close bond between language and memory is a good starting point, following Siobhan Brownlie's line of thought, wherein '[1]anguage and memory are intimately bound together, for not only is language a memorial phenomenon passed down through generations, but memory of past events, eras and traditions is embedded in language and in linguistic products' (2017, p. 1). Based on Brownlie's claim, we can anticipate translation to become a powerful tool while dealing with memory across borders and in different languages, where literary and cultural memory may not share common ground. Research centred on the interplay of language, memory, and translation studies is still in its infancy, although a growing body of scholarship from the past few decades has contributed towards understanding the importance of translation and the transmission of memory. Some of the relevant studies in this field include Brodzki (2007); Brownlie (2011, 2013, 2016, 2017); Davies (2018); Davies, Boase-Beier, Hammel, and Winters (2017); Deane-Cox (2013, 2014); Fernández Gil (2013, 2017); Spiessens and Toremans (2016); and Pintado and Castillo (2018). These works deal with the intersection of memory and translation in different locations and scenarios, such as Australia, New Zealand, the Holocaust, and Spain. The aim of 
this article is to explore whether some of the key theoretical concepts developed by scholars working in the fields of translation and memory studies are relevant to the translation of the Spanish novel La voz dormida (2002), by Dulce Chacón. The analysis of the novel is in line with Erll's (2011) model of transcultural memory, which she conceptualised as 'mnemonic processes unfolding across and beyond cultures' in which the transcultural transcends the borders of traditional cultural studies by looking beyond established research methodologies' (Erll, 2011, p. 9). At the same time, other frameworks will be treated as integral parts in the discussion on memory and translation, given the nature of the novel discussed and the disciplines involved. These include a study on postmemory by Mariane Hirsch (2001), Aleida Assmann's (2010) models dealing with traumatic pasts, and translation and memory research developed by Deane-Cox $(2013,2017)$.

Since the end of the dictatorship in Spain, and especially since the 1990s onwards, there has been a rapid growth in narratives dealing with the Spanish Civil War (1936-1939) and the dictatorship (1939-1975). These narratives have engaged new ways of memorialising this recent past. This renewed interest in the topic, a phenomenon labelled as 'memory boom' has spurred - between 2000 and 2014 - the production of over 174 first-edition novels by Spanish authors, 30 by UK authors, and 26 by US authors (Lines, 2017, p. 151). Some of the best-known novels in this space include: The Soldiers of Salamis by Javier Cercas (2003), The Frozen Heart by Almudena Grandes (2010), and The Time in Between by María Dueñas (2011). While scholarly work and narratives on the boom abound, work on memory and translation pertaining to the Spanish Civil War and the dictatorship that succeeded it continues to thrive. Recent studies in this field include Kyetris (2018), Espada Vieira (2018), and Cáceres Casillas (2018) as part of the volume New Approaches to Translation, Conflict and Memory: Narratives of the Spanish Civil War and the Dictatorship. The present article arises from the need to further explore this field.

\section{Memory in La voz dormida (2002)}

La voz dormida (2002), by Dulce Chacón, recounts the traumatic experiences of a group of four women, namely Hortensia, Tomasa, Reme, and Elvira, who were political prisoners after the Civil War (1939-1963). The narrative centres on the stories of Hortensia, a prisoner who is condemned to death and gives birth to a daughter shortly before being shot by a firing squad, and her sister Pepita, who goes on to raise the child under the memory (and inspiration) of Hortensia. This novel, critically acclaimed by the public and the press, was a milestone in the evolution and expansion of the memory boom in Spain for the recovery of the memory of the dissidents, particularly Republican women. Dulce Chacón intended to provide a platform through which to recover the memory of those voiceless women who may not have been able to tell their own stories because of the silence imposed on them by the Francoist repression that took place over several decades of the dictatorship (Domínguez, 2003). In 2002, during the launch of her book, Dulce Chacón claimed that she considered herself a part of a generation that felt responsible for the silence of their parents, a silence which, in her opinion, was a sentence imposed during the transition to democracy, one that lasted too long. Dulce Chacón argued that bringing to light the memory of the forgotten through the novel became an instrument of reconciliation (Domínguez, 2003).

Appraisals of the role of women in the resistance against Franco were not rare prior to the publication of the novel. However, these were personal testimonies and scholarly work 
which, according to Inma Chacón (2010), had failed to garner popularity among the general public. Academic work was addressed to experts in the field, and personal testimonies were limited to specific discussions in the form of debates and seminars on the recovery of historical memory. As a novel, La voz dormida reached a much wider audience. Dulce Chacón engaged in extensive work by documenting and collecting testimonies for four years before writing the novel. This study was made explicit in the novel, as the author included official documents (decrees, statutes, councils of war, and pardons), a long list of acknowledgements of those who helped her retrieve information, and the names of those who shared their stories through their testimonies.

José Colmeiro (2008) attributed the success of the book to the hybrid nature of the text: the novel presents a series of fictionalised collective testimonies in which Dulce Chacón recollected and constructed women's memories of the political resistance against Franco in the cruel years that followed the end of the war. The multiple voices in the novel transform the recollected raw material and produce what Colmeiro called a hybridization of memories' which work as an anti-institutional counter-memory (2008, p. 193). The novel was a 'cathartic experience' for many women, as it helped them break their silence on their participation in the anti-Franco resistance and share their individual memories (Colmeiro, 2008, p. 193). By telling us fictional stories based on testimonies by women who suffered repression, torture, humiliation, hunger, and fear in the prison of Ventas in Madrid, Dulce Chacón established a relationship between the individual and the collective identities, as well as between the past and the present (Castillo, 2017, p. 150). In this sense, and echoing Deane-Cox's work on mediating memory (2013, p. 309), the concepts of individual and collective memory in the novel are able to destabilise discourse on historical objectivity and can also challenge the possibilities and limits of literary representation. The novel is therefore committed to the recovery of historical memory from a different perspective in relation to earlier works. The novel relates not only to current debates on the appropriate ways of memorialising the recent past, but also reflects the needs and concerns of the present that play a significant role in the ongoing process of dealing with the past in Spain (Leggott, 2015, p. 2). The significance of Dulce Chacón's contribution is twofold as she conceives of different types of memory and connects them with the future debates on exploring the most appropriate way to come to terms with a past involving mass crimes and human rights violations.

\section{A framework for memory in La voz dormida}

There is little doubt that memory can act as a mediator of the past. New laws and policies, sociocultural demands, testimonies, and artistic representations in contemporary Spain present an endeavour to restore justice. The process of historical memory continues to evolve, but, at the same time, the presence of sensitive issues around the process still creates tensions - the most recent being the national debate on whether Franco's body should be exhumed from El Valle de los Caídos and transferred to an ordinary grave, detached from any type of homage or distinction.

Aleida Assmann (2010) put together a particularly useful framework on memory for the study of La voz dormida. She proposed different models for addressing how current societies deal with traumatic and violent pasts. According to Assman, Spain sits against the backdrop of 'dialogic forgetting', which is another form of silence, as amnesties and 
pardons have been used to achieve reconciliation between formerly opposed parties (p. 11). This model of forgetting applies to the suppression of the memory of the crimes committed by Franco's regime during and after the dictatorship. In the transition to democracy in Spain, those who had committed serious crimes were pardoned under an amnesty law that was passed in 1977. Most political leaders supported this law because they wanted to unite the country and direct its path towards a new democratic system, ignoring some of the more problematic aspects of the previous decades of Spanish history (Pintado \& Castillo, 2018, p. 4). It was only the passing of the Historical Memory Law in 2007 with the Socialist government that allowed explicit condemnation of the Fascist dictatorship and acknowledged the suffering of the victims (Stokholm Banke, 2016, p. 27). Although the passing of the Historical Memory Law was one political move towards the acknowledgement of Francoist repression, the text remains controversial as the provisions of this law deny the recognition of collective memory. In other words, the legal text does not recognise what happened as crimes against society and humanity, and therefore precludes the State's responsibility to guarantee the right to truth, justice, and reparation for the victims. These circumstances and the lack of consensus on the debate of memory among political parties prevented further development on this issue. In spite of this, there has been a shift from Assmann's model of forgetting towards one of remembering, and this has otherwise already taken place largely at the social and cultural levels. A plethora of books, films, documentaries, public debates, and commemorations at the social, national, and transnational levels contest and reinterpret this period of Spanish history. The proliferation of individual memories and the absence of official recognition create a paradox that results in the reluctance on the part of the main political actors in Spain to engage in discourse on memory and to respond to this pending issue (Colmeiro, 2018, p. 482). The models proposed by Assmann are certainly relevant to presenting $\mathrm{La}$ voz dormida as a novel that brings to the forefront recent debates on strategies for remembering to engage with a fair future. A good example of this is a passage that shows an anonymous woman cutting pieces of cloth from each of the corpses so that families can recognise their relatives: 'Y dicen, y es cierto, que una mujer se acercó a los caídos y se arrodilló junto a Hortensia. Llevaba unas tijeras en la mano. Le cortó un trocito de tela del vestido que se había puesto para morir' ( $\mathrm{a} a \mathrm{voz}$ dormida, 2002, p. 244)

[They also say, and this is true, that a woman came over to those who had been executed and knelt next to Hortensia. She was carrying a pair of scissors. She cut a small piece of cloth from the dress Hortensia put on to die]. (The Sleeping Voice, 2006, p. 149)

The question on how past events affect us so powerfully in the present is addressed by Stokholm Banke (2016, p. 22), who pointed out that we must not only consider the domestic politics involved, but we must also understand how the politics of memory have developed in Europe over the past two decades, a period in which past crimes have exerted a greater influence on foreign relations and international politics. Current attention to memory in contemporary societies is a global trend that brings about new challenges in the way in which different nations approach processes of remembrance and memorialisation. A new language of international justice, one that seeks justice for crimes in a universal jurisdiction, has emerged as a reaction to human rights violations 
(Colmeiro, 2018, pp. 481-482), and accounts such as La voz dormida clearly show this commitment to claiming justice for Francoist victims.

\section{The turn of translation and memory studies}

The interweaving of translation and memory studies has the potential to establish a powerful dialogue in which the interdisciplinary nature of both fields may result in very interesting synergies that include the implications of translating traumatic memories of past experiences; the assimilation, adaptation, or rejection of elements from other sociocultural contexts; the negotiating process across the source and the target language and culture; and the power of translation in passing on memory. Recovered memories open up narratives of the past; thus, words become 'vessels of Historical Memory: they reanimate the ghosts of the past, they replay the stories of battles, lost and won. They affirm entitlement or they speak of displacement' (Simon, 2012, p. 159). Whether it conveys entitlement or displacement, language is key in establishing a dialogue between the past and the present. This intimate bond between language and memory also applies to the intersection between translation and memory since 'as a language act, translation is also bonded with memory' (our translation, Vieira, 2018, p. 193).

The so-called 'turn to memory' allows the problematisation of memory as a mediation of the past, which in turn implies that its reconstruction may have important implications as discussed in section 2. The idea that conceptualises translation as remediation, following Deane-Cox's argument that memory studies are 'exposed to the transformative powers of linguistic and cultural reframing' (2013, pp. 309-310), is more significant for the purpose of the present article. Translation is, therefore, key in 'creating transcultural memory, that is, creating shared knowledge of the past in different countries and cultures. This knowledge includes both knowledge of historical events and knowledge of cultural items' (Brownlie, 2011, p. 3). While La voz dormida has been translated into several languages, little scholarly attention has been paid to the study of the intersection between translation and memory in this novel. $\mathrm{La}$ voz dormida actively constructs national memory as a social framework of remembrance, but its translation breaks away from the notion of national memory and then becomes an instance of transcultural memory. In this article, based on Erll's approach (2011), we will assume that memory may not be bound to a particular place and that translation allows such memory to cross territories and sociocultural borders. We must understand transcultural memory as memory that travels, that is transferred, and is thus in continual transformation through time and space, across social, linguistic, and political boundaries: 'Memories do not hold still - on the contrary, they seem to be constituted first of all through movement' (p. 11). Globalisation has accelerated this process of 'travelling memory', in which translation disseminates memory worldwide through novels, movies, and news stories - although not without tensions between the global and the local contexts. Erll (2011) conceived transcultural memory through different dimensions of movement. For the sake of the present study, we will focus particularly on carriers of memory, understood as 'the individuals who share collective images and narratives of the past' (p. 12). The novel and its translation act as carriers of memory that play a key role in generating collective memory, which allows for the exchange of mnemonic contents between individual minds, creates discourse on 
memory and commemoration, and disseminates versions of the past across languages that may affect the future.

As a result, the intersection between translation and memory gives us the possibility to keep memory alive - and to disseminate and exchange relevant information on and experiences of past events - thus modifying the construction of memory among individuals, the media, and society, and, in turn, engaging in the process of transcultural remembrance.

\section{Legitimising women's memory in The Sleeping Voice}

The overall silence over gender-based violence in women's prisons during the war, and later during Franco's dictatorship, has been invisible until very recently. Hernández Holgado explained this as 'a double process of social exclusion', in which women were both political prisoners and agents who were erased as objects of history (2003, p. 19). Dulce Chacón also noted this double historical injustice:

firstly, they lost the war, and then the post-war as they were forced into a patriarchal system where all the rights they had conquered during the Republic were lost; their role fighting in the front, in prisons, or being part of the resistance was erased. Their role was not secondary. (our translation, Domínguez, 2003)

She highlighted the remarkable role of these women as primary actors in history.

Dulce Chacón's novel is a clear manifestation of a counter-representation of history. The power of the representations illustrated in the source text (ST) may also be retained in the target text (TT), introducing new elements of counter-memory into another literary landscape and society. In this vein, the translation has the capacity to become an influencing force in the sense of the potential identified by Bassnett and Lefevere (1990, p. ix). These authors explain the power of rewriting through translation, in that it enables an interaction between the source and the target cultures and because it plays a central role in the circulation of the source culture and ideology - an argument that recaptures Brownlie's (2011) idea that translation may be key in circulating shared knowledge of the past. Translation is at the core of the circulation and reinstatement of the silent traumatic experiences of women who have remain ignored by history. This intersection between translation and memory gives rise to considerable challenges, but, at the same time, it opens up avenues to address responsibility towards the present and the future. In Bassnett's words, 'no absolutely perfect memory or absolutely perfect translation can exist. But translation, like memory, writes the future, and it does so through re-writing the past' (2003, pp. 308-309).

The Sleeping Voice (2006) acts as a carrier of the memory of women's resistance and mediates the construction of a contestatory work of literature. As a carrier of memory, translation plays a key role in the construction of the imaginary in the new culture, given its capacity to take part across different dimensions including the media, cultural artefacts, and other by-products. The Sleeping Voice, as rewritten text, is not a superfluous by-product since it reconveys the trauma and the abuse exercised on Republican women, thus legitimising their memory. Bassnett and Lefevere claimed that 'translation, like all rewritings, is never innocent' as 'there is always a context in which the translation takes place, always a history from which the text emerges and into which a text is transposed' (1990, p. 11). This idea allows for The Sleeping Voice to remain influential in recipient cultures. 
Its translation into English implies a wider circulation as 'by translating, a text reaches a wider pool of readers than the original author can ever have imagined' (Bassnett, 1997, p. 13). This adds an additional dimension to the scope of the text and the underlying forces, as translation is a dynamic force that crosses geographical and linguistic boundaries and carries the resonating voices of the victims beyond national memory. At this point, we may wonder whether translation is ultimately key to negotiating women's conflict transculturally, as, according to Baker, '[e]very time the version of the narrative is retold or translated into another language, it is injected with elements from other, broader narratives, circulating within the new setting or from the personal narratives of the retellers' (2006, p. 22). This may have further implications in the process of legitimising women's memory in the English translation.

Translation establishes a dialogue across languages and cultures and allows the memory in the text to survive (Brodzki, 2007). The translation of the title in different languages indicates how titles can affect the construction of memory in the imaginary while introducing them to a new given target culture. A quick glance at these translations will reveal the extent to which the message perpetuates across the titles: La voz dormida becomes The Sleeping Voice in English; Voix endormies (Sleepy Voices) in French; Den sovande rösten (The Sleeping Voice) in Swedish; Uśpiony głos (The Sleeping Voice) in Polish; and Le ragazze di Ventas (The Girls from Ventas) in Italian. All five titles relate closely to the novel although the translation of the original title remains almost the same in all titles but in Italian. In this case, the title The Girls from Ventas omits the reference to the voices and replaces them with the prison where the inmates served a sentence, connecting closely with Pierre Nora's (1989) concept of sites of memory. Differences are minimal among the remaining titles. The most notable case is the French title, which reflects explicitly a concept of collective memory, since it uses a plural marker and semantic nuances associated with the silence of the voice, which may have implications in one's capacity to recover the voice and guarantee the circulation of memory.

These examples illustrate how translation assists in the construction of memory and adds to the many-sided and conflicting storylines of events in the recent past in Spain. Translation is key in circulating new narratives of resistance, and in raising the issue of cultural appropriation, which is (a) responsible for circulating or neutralising resisting narratives and (b) key to mediating the representation of dissident Spanish women. This argument is in line with Castro's (2013) idea that power and ideology are closely linked to critical studies of language and translation (p. 5) and that this, in turn, can help construct transnational and transcultural realities (p. 10). Translation has the power to further legitimise a part of Spanish history that was silenced. Since we live in a global world in which local conflicts are increasingly discussed at the international level, translation is crucial for 'all parties to legitimise their version of events' (Baker, 2006, p. 1).

\section{The writer as a transmitter, the translator as a guardian}

The complex nature of the novel lies in a dynamic process that involves the following steps. First, Dulce Chacón played a pivotal role in recovering memory as she actively engaged in listening to and gathering oral testimonies. Second, she actively engaged as a reader of other testimonies and accounts, as well as of official documents. Finally, she 
engaged in passing on the memory by narrating events based on what she had listened to, read, and gathered. Retrieving remembered and experienced narratives recorded in different repositories, Dulce Chacón reworked and brought them beyond their original borders, and thus inserted them into a new setting in the realm of fictionalised memories.

Dulce Chacón's responsibility towards establishing an intergenerational bridge involves the transmission of memory, which is present both inside and outside her fictional account (Portela, 2007, p. 5). First, a transmission occurs between Dulce Chacón and the victims; second, the transmission takes place between characters in the novel (the best example being between Pepita and her niece Tensi); third, there is a transmission between the novel and the readers, many of whom belong to the third generation in line with the views of Portela (2007) and Hirsch (2001). Though fictionalised, Dulce Chacón's narrative is committed both to lived experiences that carry a complexity associated with the contingency of memory and to the transmission of those representations of memory. As DeaneCox indicated, 'survivor testimonies are generally not held to be reliable sources of fact given the reconstructive fallibility of memory and the alleged representational failings of words' (2017, p. 23). This means that the narrative reflects the tension between the testimonies and what really happened as well as the tension between the possibilities of communication restricted by trauma. Whatever the contingencies are, the author preserved a memory that would have otherwise remained silenced.

The translator should respond to these complexities and is, therefore, potentially dealing with a text charged with particular morals in the process of remembering - as is the case of La voz dormida. Translation is paramount, given the fact that it is translation that allows the memory to cross borders and to safeguard those particular morals when they cross borders. The translator, according to Deane-Cox, is a present and operative force in the bringing forth of the testimony in another language, as well as in its journey to another time and place' $(2017$, p. 95); s/he is responsible for reshaping the narrative accounts for a 'broader audience in the target culture' (p. 95). The novelty of this case study is that Dulce Chacón acted as the witness and the transmitter who mediated, on the lines of the ideas proposed by Hirsch (2001), in the realm of postmemory, unlike the figure of the translator associated with the Holocaust testimonies discussed in Deane-Cox (2017). What, then, is the responsibility of the translator in The Sleeping Voice?

Neither the author of $L a$ voz dormida nor the translator experienced the historical events. However, Dulce Chacón played an essential role in recollecting testimonies from survivors that recounted these experiences by acting as a witness while she was engaged in the documentation work she undertook. The author becomes a figure that facilitates the fictionalised transmission of the survivor's memory, and the translator, in this sense, is - to a certain extent - ethically bound to act as a guardian of the history of the survivor, wherever possible, and to convey 'those moments where communication collapses into silence or haunting returns' as indicated by Deane-Cox (2013, p. 315).

Translating a traumatic narrative like $L a$ voz dormida places the translator within a complex process in which s/he is far more involved and is no longer just standing at the epicentre of the process of communication, as understood by Hatim and Mason (1990, p. 223). S/he is bound to adopt an ethical position in which the translator is not only a communicator but also a guardian of these memories in the target language and culture. The figure of the translator as a guardian draws from Deane-Cox's framework 
(2013), with the difference that the translator is not analysed as a secondary witness in this article, as s/he does not work with testimonies, but with a fictionalised narrative that contains elements of trauma. Without proposing a prescriptive approach, and mindful of the complexities and the limits to the representation of the suffering and trauma, we suggest that the translator acts actively in the process of renegotiation. The ideologies encoded in the source narrative imply that the translator is not an impartial actor; to think otherwise would indicate 'the evisceration of the agency of the translator as a committed, engaged and responsible figure' (Tymozcko, 2007, p. 7).

\section{Memory and translation in The Sleeping Voice}

The decision to explore the translation of these accounts is based on the fact that the figure of the translator as a guardian of these memories has received relatively little critical attention. Our case study intends to critically explore the implications of translating memory as applied in practice. As Margaret-Anne Hutton claimed, the potential of words as a communication tool cannot be undermined as rhetorical works $(2005, \mathrm{p} .2)$. The translation of La voz dormida as a multi-layered novel symbolises a transition into a new coding that can potentially be vigilant of words acting as tools that express oppression, suffering, and trauma. Although the translator is considered as the guardian of the memory, it is essential to acknowledge that interested parties (publishers, editors, and literary agents) may also determine the final product and, in turn, the reception of it.

The world described by Dulce Chacón primarily represents a microcosm of female prisoners in Ventas prison, as opponents of Franco's regime (Portela, 2007). This world also represents the lack of freedom and the limits of the inmates' thoughts and interactions among themselves, with the prison guards, and with their relatives. The recovered voices analysed here are in line with Portela's concept of postmemory, which is understood as traces of memory and how their representation includes an emphasis on their transmission to future generations (2007). This is based on Hirsch's (2001) statement that presents postmemory as 'a powerful form of memory precisely because its connection to its object or source is mediated not through recollection but through representation, projection, and creation' (p. 4). Dulce Chacón belonged to a second generation that did not experience the conflict of the war and the trauma. Her family belonged to the national faction. The ethical responsibility to pass on the Republican memory became a mission for the author in an attempt to recover this legacy for future generations. Following Hirsch's 'Surviving Images', the trauma of the 'second generation' does not relate directly to the conflict but to the representation of it through testimonies, visual material, and other imprints left behind by the first generation (2001, p. 8). The hybrid technique adopted allowed Dulce Chacón to include paratextual elements such as the title of the novel, the picture on the book cover, historical documents, and the annexes at the end of the novel, which are key in the representation of memory, as they also serve to fill certain historical moments that were omitted by official accounts of history. Dulce Chacón used these paratexts to establish a dialogue among these elements, the novel, and the reader. This dialogue is perfectly illustrated in the opening of the book, which includes one of Celan's poems from Poppy and Memory (1996) originally published as Mohn und Gedächtnis (1952). This reference is not coincidental, as Celan (1920-1970), who experienced repression and trauma, is considered an instrumental author in understanding the 
loss and the recovery of language after the Holocaust (Portela, 2007, p. 2). The English version of the poem reads: 'In vain you draw hearts on the window-pane:/ down in the castle courtyard/ the lord of silence is busy lining up soldiers'. However, Dulce Chacón modified this version, introducing the figure of 'the Caudillo' (that is, the 'dictator', as Franco was known) as a reference to the silence he imposed: 'En vano dibujas corazones en la ventana:/ el caudillo del silencio/ abajo, en el patio del castillo, alista soldados' (our emphasis). These opening verses invite the reader to reflect on the content of the novel and also establish parallelisms between the experiences of the Holocaust (through Celan) and those of the Francoist regime. The Sleeping Voice overlooks this reference to el Caudillo and uses the English translation of the original poem. This implies a significant loss in the intention of reframing the ST, as the reference to el Caudillo was ignored and thus completely diluted.

These paratextual elements have an added value through translation, as they allow the recipient culture to access personal accounts and official documentation that are part of the collective imaginary in Spain, and to reach beyond, thus legitimising counter-official events in the international arena. The embedded paratextual elements are perfectly attuned to the rhetoric and writing style of the novel. The rhetorical attributes and the symbolic traits in $\mathrm{La}$ voz dormida are indeed used as mechanisms that preserve the essence of the possibilities of communication in this context. The aesthetic dimension of Dulce Chacón's narrative maintains the tension, the fear, the resistance, the sense of survival, the solidarity, and the trauma, thus upholding the testimonies from which she drew upon. The recovered voices speak of a collective memory constructed with elements of orality, giving an account of the large number of gathered testimonies and interviews. The orality of the novel, discussed at length by Colmeiro (2008), is tangible in the verbal patterns and the repetition of structures, words, and phrases that reflect the nature of memory and the suffering of life in prison. In the same manner, repression is illustrated by the presence of the silence and the importance of looks, glances, and gazes that so gracefully transmit trauma, repression, solidarity, and defiance at the same time, and that are largely successfully reflected in the translation:

En cuanto el abuelo de Elvira comienza a hablar, Pepa percibe la fragilidad en su voz. La conoce bien, esa fragilidad. Palabras a medias. Palabras buscadas y silenciadas antes de llegar a los labios. (our emphasis, 2002, p. 25)

As soon as Elvira's grandfather starts to speak, she hears how weak his voice is. She knows that fragility well. Half spoken words. Words searched for and silenced before they even reach the tip of the tongue. (our emphasis, 2006, p. 10)

A repetition of the symbolic tools for passing the memory on is also rendered through 'la maleta' (the suitcase) and 'el cuaderno azul' (the blue notebook), both of which are objects that reproduce the discourse of the responsibility of communicating life experiences to future generations. These stories of intergenerational transmission are essential, as they are reproduced in the novel (among the inmates, their families, and future generations) and in the present where readers receive previous experiences of trauma and repression and mirror the writer's intentionality, as discussed previously.

The regime of violence inside and outside the prison reveals a language of survival based on resistance and power. The repressive ruling is implied in the silences and glances that have been referred to previously, and also in their thoughts and interactions, 
which illustrate the inmates' power of resistance through sarcasm and irony, through contestatory replies and ideologies, that are at times overt, and at other times, covert. The guards in the prison, for instance, are characters that inflict torture and exercise power. Their actions, torture, and oppression cause the prisoners to call them names based on their most despicable traits in an attempt to ridicule the authoritarian figures: la Veneno is 'little miss Poison' and la Zapatones is 'Big boots'.

These small symbols of resistance, resilience, and defiance present in The Sleeping Voice are, however, not always in line with the narrative of the ST. Dulce Chacón portrayed a microworld of female prisoners ('Aquí todas somos hembras, Tomasa' [p. 61]) ['We are all women here, Tomasa' (p. 32)] guarded mostly by female guards. The men around them mostly represent the inmates' relatives, their boyfriends or husbands, and doctors or priests. In line with this, Dulce Chacón made it extremely clear that the guards are female. This is easily illustrated in Spanish, as the female article, 'la', determines the grammatical gender while referring to the guards (la Zapatones, la Veneno); but Dulce Chacón also afforded rhetorical techniques that doubly marked both the grammatical and actual gender: la guardia civila - as 'civila' is grammatically incorrect. English operates differently as the grammatical gender is generally unmarked by word-endings. The translation in English remains neutral and erases the figure of female authority, with the potential to represent a male guard:

-Habrá que avisar a la guardia civila (our emphasis, 2002, p. 206).

'We ought to tell the guard' (our emphasis, 2006, p. 125)

Franco is repeatedly ridiculed. Known widely as El Generalísimo in Spain, this designation provides him with the highest honour and respect, thus granting him a sense of greatness and magnificence. Franco, the greatest general, was ironically of short stature, and this is used throughout the narrative by the inmates to turn the Generalísimo into an object of mockery, irony, and sarcasm:

Generalísimo, masculla Tomasa entre dientes abrazándose las rodillas con rabia. Generalito lo llamaban en África, al que fuera nombrado jefe del Gobierno del Estado y Generalísimo de los Ejércitos de Tierra, Mar y Aire, el día uno de octubre de mil novecientos treinta y seis. No perdió el tiempo en quitarse el nombre de Generalito. (our emphasis, 2002, p. 212)

The Generalísimo, Tomasa mutters to herself, grasping her knees in fury. In Africa he was known as Generalito, little general, although he became Head of State and Generalísimo of the Army, Navy and Airforce on 1 October 1936. He was quick to get rid of that Generalito. (our emphasis, 2006, p. 129)

Both Generalísimo (a majestic figure) and Generalito (small and unimportant general, explained in the translation) convey the same meaning in the ST and the TT. However, the mockery may be lost in translation, as we see in the final sentence of the paragraph above, where 'enano' or 'dwarf' (which clearly intends to discredit the dictator) remains as 'Generalito', a much more neutral form that, regardless of the semantic power, is nowhere near the sarcasm used by the inmates to confront the established power:

Para cuando entren los aliados. Así que, cuando caiga Hitler, ya podemos hacer las maletas, que echan al enano (our emphasis, 2002, p. 318) 
When the allies get here. As soon as Hitler falls, we can pack our bags, because they'll be coming to throw out the Generalito. (our emphasis, 2006, p. 195)

Space limitations and the aim of this article prevent us from analysing other examples. However, the examples discussed here show the dynamics, synergies, and implications that meet at the intersection of memory and translation.

\section{Concluding remarks}

The role of the literature on memory and its translation is key in communicating a counter version of past conflicts from the twentieth century. Based on Bakhtin (1981), Lines highlighted the potential of novels to encapsulate the complex and multi-layered relationships involving lived experiences (2017, pp. 150-151), in this case, experiences of violence and trauma studied in this article. Following this idea, both La voz dormida and The Sleeping Voice contribute to the (re)construction of memory, thus progressing towards a restorative justice process that is linked with political and social action. By inserting this study within the overarching frameworks of transcultural memory and the translator as a guardian, we examined how cultural representations can contribute to constructing discourses of memory and restoring justice internationally.

The turn to translation and memory studies proposed in this article gains more relevance when explored alongside the power turn of translation that appeared in the early 2000s (see Gentzler \& Tymoczko, 2002; Gómez Castro, 2019). These turns offer new possibilities to further examine the translator's agency and other sociocultural aspects. The representation of memory and gender explored in La voz dormida and The Sleeping Voice highlight the significance and the power of rewriting literature across cultures.

The translator, as an agent who recreates a counter-memory in a different landscape, in which the cultural references and the imaginary are different, faces challenges. New ways of constructing and memorialising the conflict from Spanish accounts are not widely known in other countries, and the concepts, images, and knowledge associated with the conflict, like that of el Caudillo, are lesser known. For the purpose of the current exploration, we can conclude that challenges in the translation include a mismatch of the imaginary between the potential Spanish- and the English-speaking receivers; the fact that Dulce Chacón was not alive when the novel was translated; the use of language strategies and references to folk culture in the novel that transmit narratives of complex relationships of suffering, trauma, and power; and the act of addressing the poetics and rhetoric in this hybrid text. While there is a general consensus that the translated version conveys the type of memory constructed by the original novel, there are also instances where the English version neglects to deliver the intention of the author accurately; for instance, certain nuances disappear or fade, and there are few explanations and no translator's notes.

This discussion provides evidence to endorse the value of translations as textual sites that transmit memory to another level, in line with Davies' approach (2018) and with perspectives emphasising the implications of translation in the (re)construction of imaginaries reflected in the new receiving society. The narratives dealing with the past define and determine the present and the potential ways to memorialise experiences of these dissident women in the future, thus opening up new paths to remember the traumatic experiences of a turbulent past. We trust this work will inspire future research on memory and 
translation as a powerful force and ensure the passing on of values like integrity and justice to future generations.

\section{Disclosure statement}

No potential conflict of interest was reported by the authors.

\section{Funding}

This work was supported by the Faculty of Humanities and Social Sciences at Dublin City University.

\section{Notes on contributors}

Alicia Castillo Villanueva is Assistant Professor of Spanish at the School of Applied Language and Intercultural Studies at Dublin City University. Her current research revolves around the intersection of translation, conflict and memory studies. She also explores cultural representations of gender and sexuality. Her latest publications include the edited book New Approaches to Translation, Conflict and Memory: Narratives of the Spanish Civil War and the Dictatorship (2018, Palgrave McMillan), 'The Recession in Contemporary Spanish Cinema: Masculinities in Transition' (2017, Routledge), 'Narratives of Violence and Resistance in Spanish Women Writers' (2017, Arabesques Editions).

Lucía Pintado Gutiérrez is Assistant Professor at the School of Applied Language and Intercultural Studies in Dublin City University. Her research is based at the intersection of translation, conflict and memory studies. She also explores the developing field of language education and pedagogical translation. Her publications include journal articles, book chapters, and edited volumes on translation and Spanish historical memory; the students' agency and pedagogical translation; translation within a communicative framework; and discourse, text genres and translation. Her latest publications include the edited book New Approaches to Translation, Conflict and Memory: Narratives of the Spanish Civil War and the Dictatorship (2018, Palgrave McMillan), 'Translation in Language Teaching, Pedagogical Translation, and Code-Switching: Restructuring the Boundaries' (2018, The Language Learning Journal).

\section{References}

Assmann, A. (2010). From collective violence to a common future: Four models for dealing with a traumatic past. In H. Gonçalves da Silva (Ed.), Conflict, memory transfers and the reshaping of Europe (pp. 8-23). Newcastle upon Tyne: Cambridge Scholars Publishing.

Baker, M. (2006). Translation and conflict: A narrative account. London \& New York, NY: Routledge.

Bakhtin, M. (1981). The dialogic imagination: Four essays. Austin: University of Texas.

Bassnett, S. (1997). Introduction. Intricate pathways: Observations on translation and literature. In S. Bassnett (Ed.), Translating literature (pp. 1-13). Cambridge: Brewer.

Bassnett, S. (2003). Translation as re-membering. In E. Caldicott, \& A. Fuchs (Eds.), Cultural memory: Essays on European literature and history (pp. 293-309). Oxford: Peter Lang.

Bassnett, S., \& Lefevere, A. (1990). Translation, history and culture. London: Printer Publishers.

Brodzki, B. (2007). Can these bones live? Translation, survival, and cultural memory. Stanford: Stanford University Press.

Brownlie, S. (2011). History, memory and translation: The case of Hachette Jeunesse's Ivanhoé. Palimpsestes, 24, 23-40. 
Brownlie, S. (2013). Translation and the (de)construction of memory in a network of great historical documents. Translation Studies, 6(1), 48-63. doi:10.1080/14781700.2012.727632

Brownlie, S. (2016). Mapping memory in translation. Houndmills, Basingstoke: Palgrave Macmillan.

Brownlie, S. (2017). Institutional memory and translating at the DGT. The Translator, 23(1), 1-16. doi:10.1080/13556509.2016.1201636

Castillo, A. (2017). Narratives of violence and resistance in Spanish women writers. In H. Ben Driss, \& M. Sellami (Eds.), Women, violence and resistance (pp. 139-154). Tunis: Arabesques Editions.

Castro, O. (2013). Introduction: Gender, language and translation at the crossroads of disciplines. Gender and Language, 7(1), 5-12.

Cáceres Casillas, P. (2018). Memory and translation in La cabellera del Shoá [The Hair of the Shoah] (2015) by Félix Grande. In L. Pintado \& A. Castillo (Eds.), New approaches to translation, conflict and memory: Narratives of the Spanish Civil War and the dictatorship (pp. 207-226). Cham, Switzerland: Palgrave Macmillan.

Celan, P. (1996). Selected poems (M. Hamburguer \& C. Middleton, Trans.). London: Penguin.

Cercas, J. (2003). The soldiers of salamis (A. McLean, Trans.). London: Bloomsbury.

Chacón, D. (2002). La voz dormida. Madrid: Alfaguara.

Chacón, D. (2006). The Sleeping Voice. (N. Caistor, Trans.). London: Harvill Secker.

Chacón, I. (2010, November). La mujer y la literatura sobre memoria histórica. Paper presented at the Semana de la Ciencia Conference, Universidad Carlos III de Madrid.

Colmeiro, J. (2008). Re-collecting women's voices from prison: The hybridization of memories in Dulce Chacón's La voz dormida [Special issue]. Foro Hispánico: Revista Hispánica de Flandes y Holanda, 31(January), 191-209.

Colmeiro, J. (2018). Unraveling memories in Spain. Journal of Spanish Cultural Studies, 19(4), 481490. doi:10.1080/14636204.2018.1524996

Davies, P. (2018). Witness between languages: The translation of Holocaust testimonies in context. Rochester, NY: Camden House.

Davies, P., Boase-Beier, J., Hammel, A., \& Winters, M. (Eds.). (2017). Translating Holocaust lives. London: Bloomsbury-Continuum.

Deane-Cox, S. (2013). The translator as secondary witness: Mediating memory in Antelme's L'espèce humaine. Translation Studies, 6(3), 309-323. doi:10.1080/14781700.2013.795267

Deane-Cox, S. (2014). Remembering Oradour-sur-Glane: Collective memory in translation. Translation and Literature, 23, 272-283. doi:10.3366/tal.2014.0156

Deane-Cox, S. (2017). Remembering, witnessing and translation: Female experiences of the Nazi camps. Translation: A Transdisciplinary Journal, 6, 91-130.

Domínguez, J. A. (2003, March). Entrevista con Dulce Chacón. Rebelión Cultural. Retrieved from https://www.rebelion.org/hemeroteca/cultura/dulce230303.htm

Dueñas, M. (2011). The time in between (D. Hahn, Trans.). New York, NY: Atria Books.

Erll, A. (2011). Travelling memory. Parallax, 17(4), 4-18. doi:10.1080/13534645.2011.605570

Fernández Gil, M. J. (2013). Traducir el horror: la intersección de la ética, la ideología y el poder en la memoria del Holocausto. Frankfurt am Main: Peter Lang.

Fernández Gil, M. J. (2017). La memoria del Holocausto en España a través de sus políticas de traducción. In I. Hernández González, \& A. López Fonseca (Eds.), Literatura mundial y traducción (pp. 227-236). Madrid: Síntesis.

Gentzler, E., \& Tymoczko, M. (2002). Introduction. In E. Gentzler, \& M. Tymoczko (Eds.), Translation and power (pp. xi-xxviii). Boston, MA: University of Massachusetts Press.

Gómez Castro, C. (2019). Translation choices as sites of state power: Gender and habitus in bestsellers in Franco's Spain. In S. Baumgarten, \& J. Cornellà-Detrell (Eds.), Translation and global spaces of power (pp. 109-124). Bristol: Multilingual Matters.

Grandes, A. (2010). The Frozen Heart (F. Wynne, Trans.). London: Weidenfeld \& Nicolson.

Hatim, B., \& Mason, I. (1990). Discourse and the translator. London: Longman.

Hernández Holgado, F. (2003). Mujeres encarceladas. La prisión de Ventas: de la República al franquismo, 1931-1941. Madrid: Marcial Pons, Ediciones de Historia. 
Hirsch, M. (2001). Surviving images: Holocaust photographs and the work of postmemory. The Yale Journal of Criticism, 14, 5-37. doi:10.1353/yale.2001.0008

Hutton, M.-A. (2005). Testimony from the Nazi camps: French women's voices. London \& New York: Routledge.

Kyetris, K. (2018). The translation of memory through television: El tiempo entre costuras and the Spanish Civil War. In L. Pintado \& A. Castillo (Eds.), New approaches to translation, conflict and memory: Narratives of the Spanish Civil War and the dictatorship (pp. 163-184). Cham, Switzerland: Palgrave Macmillan.

Leggott, S. (2015). Memory, war and dictatorship in recent Spanish fiction by women. Lewisburg, PA: Bucknell University Press.

Lines, L. (2017). Representations of the Spanish Civil War in twenty-first century anglophone novels (2000-14). Journal of War and Memory Studies, 10(2), 150-164. doi:10.10810/ 17526272.2016.1215051

Nora, P. (1989). Between memory and history: Les Lieux de Mémoire. Representations, 26, 7-24.

Pintado, L. \& Castillo, A. (2018). Emerging trends in reassessing translation, conflict, and memory. In L. Pintado \& A. Castillo (Eds.), New approaches to translation, conflict and memory: Narratives of the Spanish Civil War and the dictatorship (pp. 3-20). Cham, Switzerland: Palgrave Macmillan.

Portela, E. (2007). Hijos del silencio: Intertextualidad, paratextualidad y posmemoria en La voz dormida de Dulce Chacón. Revista de Estudios Hispánicos, 41, 1-21.

Simon, S. (2012). Cities in translation: Intersections of language and memory. London \& New York: Routledge.

Spiessens, A., \& Toremans, T. (2016). Presentation: Translating testimony. Temoigner: Entre Histoire et Mémoire, 123, 50-55.

Stokholm Banke, C. F. (2016). Global memory and dialogic forgetting: The Armenian case. In T. Sindbæk Andersen, \& B. Törnquist-Plewa (Eds.), Disputed memory: Emotions and memory politics in central, eastern and south-Eastern Europe (pp. 21-36). Berlin: Walter de Gruyter.

Tymozcko, M. (2007). Enlarging translation, empowering translators. Manchester: St. Jerome Publishing.

Vieira, I. (2018). Voices, whispers and silence: Translating defeat and building memories of the Spanish Civil War and Francoism (185-205). In L. Pintado \& A. Castillo (Eds.), New approaches to translation, conflict and memory: Narratives of the Spanish Civil War and the dictatorship (pp. 185-205). Cham, Switzerland: Palgrave Macmillan. 